\title{
Desmitificando a loucura: breve reflexão sobre o livro "A Psicose", de Andréa M. C. Guerra
}

GUERRA, Andréa M. C. A Psicose. Rio de Janeiro: Zahar, 2010.

\author{
Jacqueline de Oliveira Moreira*
}

\begin{abstract}
Não me atrai aquilo que não posso almejar. Se, apesar de tudo, eu escrevo, faço-o tão somente com a intenção de que quem seja tão feliz quanto eu, ao ler isto, lembre-se de sua felicidade; e que aquele que tenha dúvidas a respeito, ao ler este texto, seja conquistado por essa felicidade. (Kierkegaard)
\end{abstract}

\section{A} felicidade se apresenta no momento em que se conclui a leitura de "A Psicose", de Andréa M. C. Guerra, visto que a obra é uma viva demonstração da possibilidade de transmissão. A reação que se tem ao primeiro contato com o livro, como objeto físico, considerando o título e seu tamanho, é de surpresa. Como deslocar os sujeitos/leitores de uma "posição histórica e culturalmente preconceituosa” em relação à loucura? Como revelar que "profissionais competentes, pais zelosos e amigos leais" podem ser psicóticos? (Guerra, 2010, p. 11). A autora acolhe essa tarefa com elegância e erudição.

O tema da psicose é apresentado com base no referencial da psicanálise freudiana e lacaniana. Esses teóricos ousaram pensar e intervir em um campo que o pensamento moderno havia condenado à exclusão. A racionalidade moderna, no mesmo ato, funda a loucura, como entidade antropológica e verdade conceitual, mas a exclui da ordem social. No mundo pré-moderno, a loucura é suportada no cotidiano das cidades. Essa posição é denominada concepção trágica de loucura. A palavra trágica revela a dimensão de repetição e a dificuldade de sair desse quadro. $\mathrm{O}$ mundo moderno instaura o ideal da razão, e assim a loucura ocupa o lugar do contraponto; ela oferece as bordas definidoras da identidade moderna. Essa concepção de loucura é denominada crítica. A psicanálise freudiana propõe uma retomada modificada da concepção trágica. É preciso acolher a loucura e buscar seus sentidos sob a égide da interpretação.

Doutora em Psicologia Clínica PUC São Paulo, mestra em Filosofia pela UFMG, professora do Programa de Pós-graduação em Psicologia da PUC Minas. 
A loucura não é uma exclusividade da psicose, pois, na histeria ou na neurose obsessiva, o sujeito pode se apresentar de maneira insana. A reflexão de Guerra (2010), entretanto, localiza-se no campo da psicose. Nesse sentido, a autora oferece as reflexões freudianas sobre a relação ente representação palavra e representação coisa, o tema da neurose narcísica com as limitações da transferência e a estabilização psicótica a partir da leitura do caso Schreber. Dessa forma, a autora respeita os movimentos da produção freudiana sobre a psicose. Pareceu-nos interessante a decisão da autora de anunciar a discussão freudiana sobre "a Neurose narcísica e apresentar o problema das palavras tomadas como coisas" (Guerra, 2010, p. 13).

Freud revela que "todos os observadores se surpreendem com o fato de que muito do que é expresso na esquizofrenia como sendo consciente na neurose de transferência só pode revelar sua presença no inconsciente através de análise" (Freud [1915], p. 225). Para a psicanálise freudiana, o momento do surto psicótico é aquele em que o sujeito se eclipsa; quando, diante da frustração da perda do objeto, retorna a libido para si, procurando investir desesperadamente no seu ego. Por isso a nomenclatura neurose narcísica. Nesse movimento desesperado para se sustentar, o psicótico perde o contato com a realidade e com o encontro intersubjetivo, restando-lhe o circuito autoerótico de um corpo esfacelado. Uma possibilidade de saída desse circuito autoerótico seria o delírio sistematizado, que possibilita o equilíbrio da cadência pulsional, criando condições para o encontro com o outro. A sistematização do delírio aparece como uma possibilidade de o psicótico retomar o circuito da alteridade. O delírio ordenado apresenta-se como um objeto para a pulsão, contendo o excesso pulsional gerador do enlouquecimento da cadência rítmica da pulsão. Essa sistematização deve ser mediada pelo outro, e a presença do outro na ordenação possibilita a estabilização.

Lacan, leitor minucioso do texto freudiano e atento aos acontecimentos de seu tempo, avança na compreensão da psicose, e contribui para a intervenção neste campo. Como Guerra (2010) revela, o pensamento lacaniano não desconsidera a colocação freudiana da dificuldade da transferência na psicose. $\mathrm{O}$ estudo cuidadoso da relação entre psicose e transferência possibilita a construção da ideia de erotomania, que "implica uma forma de amor projetiva, exacerbada e delirante que precisa ser manejada a fim de que o psicótico possa produzir, durante seu percurso analítico, uma solução subjetiva" (Guerra, 2010 , p. 8). Seguindo ainda a trilha deixada pelo pensamento freudiano, Lacan trabalha com a ideia de estabilização na psicose, apontando, assim, três possibilidades, a saber: a passagem ao ato, a metáfora delirante e a obra. A reflexão da passagem ao ato sugere que esta representa uma tentativa do 
psicótico "de extrair aquilo que, em excesso, inunda o sujeito de imagens alucinadas e de sofrimento", mas não necessariamente favorece o enlaçamento social (Guerra, 2010, p. 10). A ideia da construção da metáfora delirante segue os movimentos freudianos que se iniciaram com o estudo de Schreber. Lacan, no entanto, avança na compreensão da estabilização na psicose ao estudar a função da escrita em James Joyce.

Podemos concluir, afirmando que a obra de Guerra (2010) tem sua complexidade, mas que prioriza a transmissão. O livro apresenta a psicose de Freud a Lacan, não foge das dificuldades conceituais e, ainda, oferece à comunidade científica um material inteligível.

Esta resenha é um pequeno convite à leitura de uma obra delicada e inteligente que apresenta um tema complexo com seriedade e leveza. Espero que vocês sejam tão felizes quanto eu ao ler "A Psicose", de Andréa M. C. Guerra.

\section{Referências}

Freud, Sigmund. (1974). O inconsciente. In: Edição standard brasileira das obras psicológicas completas de Sigmund Freud. (Jayme Salomão, trad., Vol. 14). Rio de Janeiro: Imago. (Texto original publicado em 1915)

Freud, Sigmund. (1974). Neurose e psicose. In: Edição standard brasileira das obras psicológicas completas de Sigmund Freud. (Jayme Salomão, trad., Vol. 19). Rio de Janeiro: Imago. (Texto original publicado em 1924 [1923])

Guerra, Andréa M. C. (2010). A psicose. Rio de Janeiro: Zahar. 